\title{
THE ANALYSIS OF COLLOCATION IN DISCUSSION PAPERS AT AL MARKAZ FOR KHUDI ENLIGHTENING STUDIES (MAKES) IN MAKASSAR
}

\author{
Bustang 1, \\ ${ }^{1}$ Sekolah Tinggi Kesehatan YAPIKA, Makassar, Indonesia
}

\begin{abstract}
The research is aimed to know lexical collocation in writing production committed by MAKES Member at al Markaz for Khudi Enlightening Studies (MAKES) Makassar. The result of this research is expected to give benefits for the EFL/ESL learner especially in using English collocation in all English skills. This research used descriptive qualitative method. The populaton of this research is about 30 respondents and sampling 15, period of 2015-2016. In this research the writer took only 4 selected writing productions to be analyzed. The analysis data indicated that there were lexical collocations in each informant's writings. Although, there were a tendency of difficulty of informants to use lexical collocation type L3. These showed by the higher number of errors occurrence in this type. Moreover, the errors occurrence, in fact, mostly, affected by the lack of understanding of the using collocation, negative transfer from their native language and the improper way in assembling the two-words. It was stated that the MAKES members need to improve their English comprehensively, particularly the awareness of using the correct and effective lexical collocation in their writing production.
\end{abstract}

Keywords: Collocations, Discussion, Papers

\section{INTRODUCTION}

In the present age, the vast of information and technology rapidly demand people to be able to be master in foreign languages, particularly, English. It is widely used in all over the world. It is aimed to get beneficial within the global competition.

English as Foreign Language (EFL) known consists of four skills, such as speaking, writing, listening and reading. Those skills have their own difficulties. Like writing, in average, EFL learners assumed experience difficulties on composing writing. Therefore, in Indonesia, in the beginning of educational degree until tertiary education levels, writing skill is taught. 
Commonly, EFL learners' writing experience severe problem such as grammatical problem, mechanical problem, wrong organizing of the idea, and wrong use of words or wrong combination of words. Wrong word combination, the misusing of the natural word in same atmosphere, i.e. do suicide, it is wrong words combination but it must be commit suicide another example, do research, it is also have wrong word natural combination. Moreover, as Hill in Kuo (2009: 141) point out, teachers tend to focus on correcting grammatical mistakes, failing to notice those mistakes which are made due to a lack of collocation. Consequently, although accurate grammar is used, problems concerning area such as lexical selection still remain. It is reasonable that learners continue to make such mistake considering the teacher's focus on grammar rather than collocation instruction. It is self evidence that teaching of collocation should be a top priority in every language course.

Regarding with word combination problems, EFL cannot combine word freely because each words has their own natural combination which is appears together which called collocation. Furthermore the co-occurrences of two words adhere to some grammatical principles. The English prepositional phrase, at the moment, for example, is subject to grammatical choice of the prepositions at rather than other random preposition like on or in. Another example is verbal phrase (look forward to) followed by gerund and not infinitive.

Benson in Hamdi (2013: 3) pointed out that collocation is categorized in two: lexical collocation and grammatical collocation. Lexical collocation consists of nouns, verbs, adjective and adverbs. A grammatical collocation consist of content words; a noun, an adjective or a verb plus a preposition or infinitive. English as Foreign Language (EFL) learner makes mistakes in using collocation. Like Devinci in Hamdi (2013: 3) said that the problem is based on some factors: the first is intralingua problem in which EFL do, for instance much money that might be saying many money. The second is interference of mother tongue, for instance make homework, in which Indonesians" habit use "make" to describe an activity, than instead of do homework. The third is over generalization, regularly, Indonesians' assumed that "put off" opposite of "put on". Yet, they are have different meaning, "put off" meaning is delay than "put on" is placing something. The last one is idiomatic, there are some idiom expression that still new in Indonesian language structure, so Indonesians' learner are confused. Therefore, collocation understanding should be known by EFL student, although it is felt difficult but by knowing it, it is very helpful for them to be able to compose a great writing.

The purpose of this study is to see and to analyze the collocation in alMarkaz for Khudi Enlightening studies (MAKES) discussion papers. By some categories of collocation, the researcher limited in the scope of research in two lexical collocations, verb + noun and adjective + noun. Also, according al Zahrany in Hamdi (2013: 3), those types collocations are typical frequently error collocation appeared. 
Due to the explanation above, the research undertaken the research entitled The Analysis of Collocation in Discussion Papers at Al Markaz for Khudi Enlightening Studies (MAKES) in Makassar.

\section{METHODOLOGY}

The writer applied descriptive qualitative method by taking writing production from each informant. It would describe the use of lexical collocation, verb + noun and adjective + noun patterns on MAKES members' essays. The population of this research was 30 informants of MAKES executive members This research applied cluster total sampling technique. The entire of selected members' writings had similar characteristics chosen by using lottery system. The writer used 15 informants, in total sample of each division. Total number of the sample was 15 discussion papers. It took weekly latest writing production which based on the suggestion of advisor research. The writer took about 15 latest writing productions which were used in weekly regular discussion program of MAKES, and these were selected by 4 papers and analyzed them. The writings were composed by the various themes; it depended on the writer's interests. And according to the informants, these writing are going to be used for discussion paper purposes in a period of time. To analyze the informants' collocation, the writer used descriptive qualitative research.

\section{FINDINGS}

After analyzing the data, thus the two followed Bar Charts would show the overview of collocation existed in MAKES discussion papers. Bar Chart I, the collection of Collocation pattern L1 (verb+ noun) taken from informants of study.

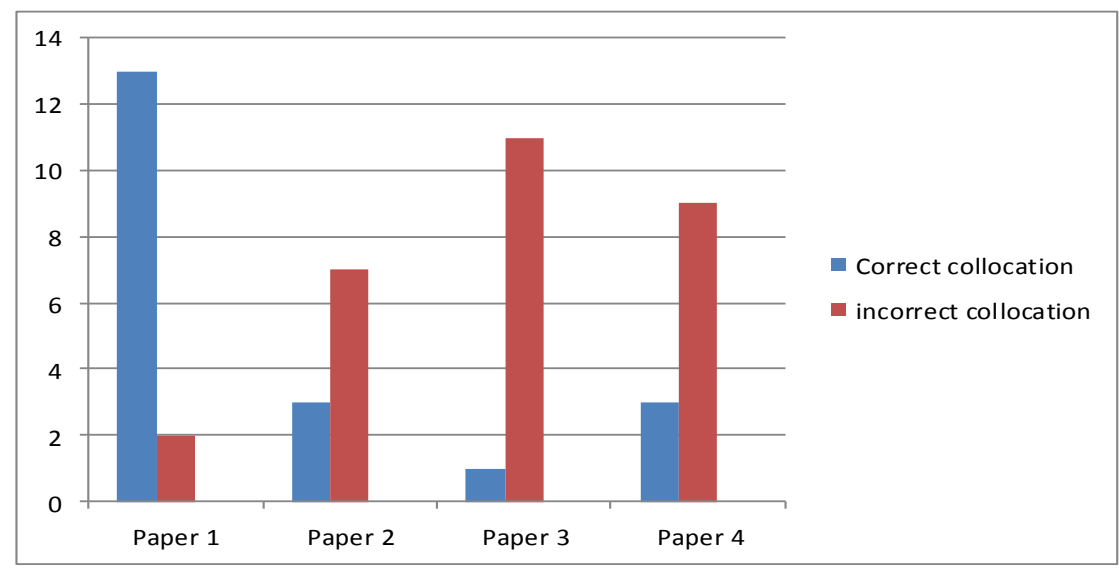

Source: MAKES Writing Production: 2016

It is obviously seen in Bar chart I, there were lexical collocation committed by MAKES essays. Despite only a few was correct collocations existed. For paper 1, it showed at two correct collocations (Collocation Dictionary: 2016) and three incorrect collocations. Next, paper 2 has only one correct collocation and five 
incorrect collocations. Furthermore, paper 3 has two correct collocations but there was not any incorrect collocation. The last, it was paper 4; it indicated there were 3 correct collocations and two incorrect collocation.

Even though the whole papers exist some collocations, but the writers were tend to use the wrong collocation, particularly in paper 2. It was significant differences between correct and incorrect collocations.

Bar Chart II. The collection of Collocation pattern L3 (Adj. +noun) taken from informants of study.

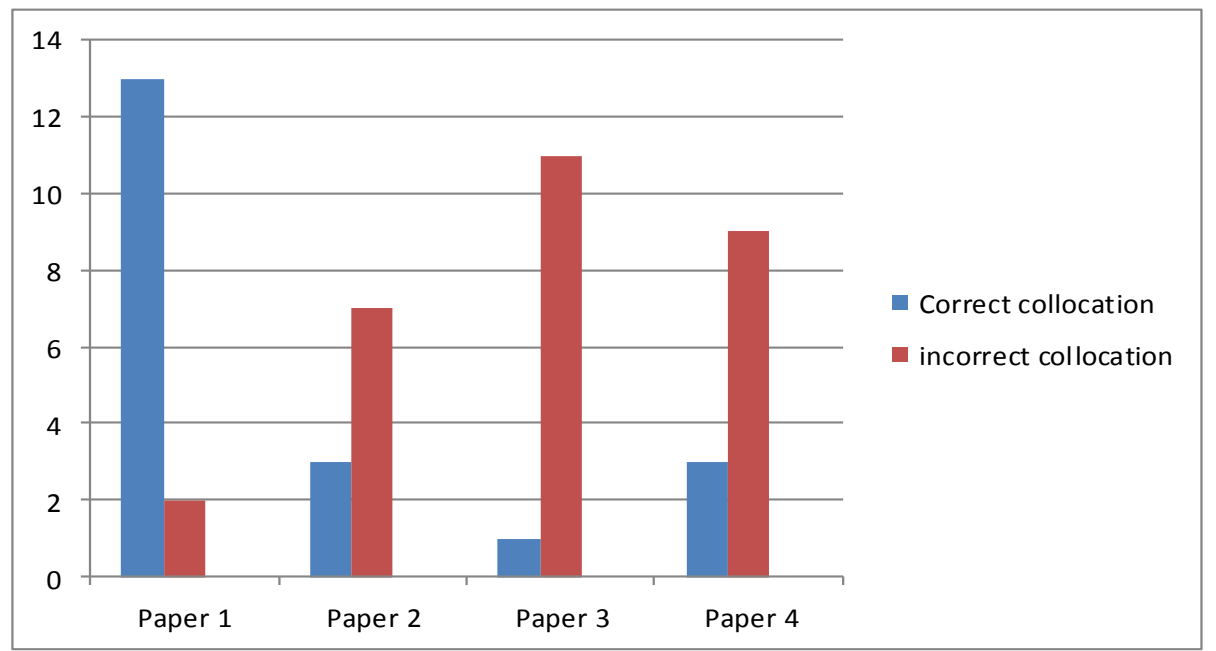

Source: MAKES Writing Production: 2016

The Bar Chart II, it is showed the total number of collocation, Adj. + noun, existed in four discussion paper or essay of MAKES. It can be seen that in paper 1, there were fourteen correct collocations found and only two incorrect collocations. In another site, paper 2 had three correct and seven incorrect collocations. It was different between paper 1 and 3 , in paper 3 , it only had 1 correct and 11 incorrect collocation, the last feature was paper 4, and it had three correct and 9 incorrect collocations (Collocation Dictionary: 2016).

Overall, Adj. + noun pattern shows higher number of collocation committed than verb + noun pattern (see bar chart I: 1). In contrast, these incorrect lexical collocation dominated. It mostly associates two words inappropriate ways, therefore, the used of word incorrectly, interlingua problem, overgeneralization rules, negative transfer from their mother tongue, lack of collocation concept and using direct method translation (Liu in Parisa, 2012: 63 and Devinci in Angkana, 2000: 29)

\section{Paper 1}

\section{a. Pattern Verb + Noun Collocation}

In this paper, it is found that there were 2 correct collocations and 3 incorrect collocations. For more detailed the following explanation below: 


\section{Correct collocation, $\mathrm{V}+\mathrm{N}$}

These two combining words below are associated correctly (Collocation Dictionary: 2016), and produce natural sounding both in speech and writing (Oxford collocation Dictionary in Mounya, 2010: 30)

a. Pay attention (See, comment: T5)

b. Designed curriculum (See, comment: T6)

\section{Incorrect collocation $\mathbf{V}+\mathbf{N}$}

The following examples are incorrect collocation co-occurrence in this subject study. It was analyzed using collocation dictionary: 2016, and Longman Dictionary Contemporary English: 2009)

a. Lead student (See, Comment : T10)

b. Run test (See, Comment: T4), It is not categorized as correct collocation due to incorrectly collocated (Oxford collocation Dictionary: 2002), "run test" is wrong collocation instead of "take a test". These words combination are improper way, "run" should be change to "take". According to Liu in Parisa (2012: 63), EFL students often assemble one word to another in a wrong way. Hence, they are lack of collocation concept; some students only understood the basic meaning of the word but did not know which word it will go with. Thus they are not competent to produce any collocation.

c. Take training (See, Comment : T6)

\section{b. Collocation Pattern Adjective + noun}

It was found that were 13 correct collocation and 3 incorrect collocation, the following detailed information about correct collocation pattern Adj. + N

1. Correct collocation Adj. + n

a. Compulsory subject(See, Comment : T1)

b. Support facilities (See, Comment : T3)

c. Long duration (See, Comment : T4)

d. Big cities (See, Comment : T7),

e. School curriculum (See, Comment : T9),

f. School teacher (See, Comment : T12)

g. Rural area (See, Comment : T18),

h. Learning process See, Comment : T20)

i. Limited access (See, Comment: T21),.

j. High score (See, Comment : T11),

k. Teaching qualification (See, Comment : T17),

1. Successful learning (See, Comment : T8),

2. Incorrect Collocation, Adj. $+\mathbf{N}$ pattern

1. Complementary skill (See, Comment : T2)

2. Teacher candidate (See, Comment : T13),

3. Micro teaching (See, Comment : T15),

It is obviously seen that paper 1 was found the number of collocation, which dominated by Adj. + noun pattern of collocation, by 12 correct and 3 incorrect 
collocation. Then verb + noun pattern only has 2 correct and 3 incorrect collocations.

2. Paper 2

a. Pattern Verb + Noun Collocation

In this paper, it is found that there were 1 correct collocation and 5 incorrect collocations. For more detailed the following explanation below:

\section{Correct collocation}

a. Launch ballistic missile (see, comment: T3)

\section{Incorrect collocation}

b. Get panic (see, comment: T4), these combination of words are claimed as wrong collocation, hence, the word form errors. "Get" is a lexical word that should be add preposition "into" to separate with "panic". Thus, "get into panic" is a correct collocation (Collocation Dictionary: 2016). Moreover, direct translation is also being the main problem of this errors concurrence, some student only remember their mother language translation of the words. Therefore, they relied on direct translation to produce collocations (Liu in Parisa 2012:63)

c. Kill people (see, comment: T5)

d. Enrich country (see, comment: T14)

e. Go bankrupt (see, comment: T15).

f. Provide scholarship (see, comment: T16)

b. Pattern Adjective + noun

It was found that were 3 correct collocation and 7 incorrect collocation

\section{Correct collocation}

a. Atomic bomb (see, comment: T6)

b. Medical science (see, comment: T10)

c. Music industry (see, comment: T11)

\section{Incorrect collocation}

a. Arrogant country (see, comment: T1), these words combination were stated as incorrect collocation due to the overgeneralization of the meaning. LDOCE define "arrogant" is behaving in unpleasant or rude way because the thought his(r) is more important that other. It is indicated, based on this definition, that "arrogant" in contextually used to describe the human behavior, not a thing like "county". In another word. It is said that errors occurs caused by the direct translation method used by the writer (Liu in Parisa, 2012: 63)

b. Nuclear technology (see, comment: T2)

c. Weapon issue (see, comment: T7)

d. True threat (see, comment: T8).

e. Referral center (see, comment: T9)

f. Abundant opportunity (see, comment: T12)

g. Prestigious scholarship (see, comment: T13) 
It can be seen that the number of correct Adj. + noun is more than $\mathrm{V}+$ noun collocation pattern. In contrast with the number of incorrect collocation this was dominated by Adj. $+\mathrm{N}$ than $\mathrm{V}+\mathrm{N}$.

3. Paper 3

a. Pattern Verb + Noun Collocation

In this paper, it is found that there were 2 correct collocations and 0 incorrect collocations. For more detailed the following explanation below:

1. Correct collocation

a. Earn income (see, comment: T6)

b. Increase demand (see, comment: T13)

\section{b. Pattern Adjective + noun}

It was found that there were 1 correct collocation and 10 incorrect collocations,

1. Correct collocation

a. Law enforcement (see, comment: T3)

2. Incorrect collocation

a. Sexual service (see, comment: T1) these combination of words claimed as a incorrect collocation due to the contextual errors. "sexual service", can be changed to "prostitution". Again, this errors committed caused by the lack of collocation concept and direct translation cases (Liu in Parisa, 2012:63)

b. Moral degradation (see, comment: T2)

c. Law protection (see, comment: T3)

d. Decent work (see, comment: T5)

e. Immoral practice (see, comment: T7)

f. Adequate education (see, comment: T8)

g. Sinful act (see, comment: T9)

h. Selling sex (see, comment: T10)

i. Legal prostitution (see, comment: T11)

j. Unlawful trades (see, comment: T12)

To sum up, the informant used many pattern of Adj. $+\mathrm{N}$, but the words combination that he(s) composed was improper way. It stated that the informant is less of strategy of synonymy (Farghal and Obiedat in Angkana, 2000: 40).

4. Paper 4

a. Pattern Verb + Noun Collocation

It was found that were 3 correct collocation and 2 incorrect collocation,

1. Correct collocation

a. Implement system (see, comment: T1)

b. Create chaos (see, comment: T3)

c. Seize power (see, comment: T9)

2. Incorrect collocation

a. Drive policy (see, comment: T11), these words combination claimed as a errors, hence, the improper word combination committed. "Policy" is a lexical word that should be assemble with "operate" (Collocation Dictionary: 2016) moreover, this case emerges caused by Interlingua 
problem (Devinci in Angkana, 2000: 29). "Drive" in Bahasa mean mengendarai atau menjalankan the writer thought that "drive" could be assemble with policy, because of his(r) understanding menjalankan peraturan same as "drive policy" meanwhile in English we cannot say "drive policy" instead "operate policy".

b. Apply party (see, comment: T14)

\section{b. Pattern Adj. + Noun Collocation}

It was found that there were 3 correct collocations and 8 incorrect collocations,

\section{Correct collocation}

a. Unstable situation (see, comment: T4)

b. Religious ideology (see, comment: T8)

c. Clear majority (see, comment: T12)

\section{Incorrect collocation}
a. Real liberty (see, comment: T2)
b. Superior country (see, comment: T5)
c. Simple choice (see, comment: T6)
d. Main ideology (see, comment: T7)
e. Real example (see, comment: T10)
f.Stable condition (see, comment: T13)
g. Potential chaos (see, comment: T15)
h. Unstable country (see, comment: T16)

In briefly, the informant used many pattern of lexical collocation, particularly Adj. + noun. But its collocation mostly is wrong. The limited knowledge of restricted collocation was the cause of that (Howard in Angkana, 2000: 40)

\section{DISCUSSION}

Collocation is an essential part in English; hence by committing correct collocation, the writing or speech will produce natural sound (Oxford collocation Dictionary in Mounya, 2010: 30). Moreover, it also potentially enable to exploit a wider range of language and get more marks in exams, and lastly, the combination of the words will be more accurately (Felicity and Michael, 2008: 6).

The description of the data collection through writing productions in previous subchapter showed the number of lexical collocation, verb + noun and Adj. + noun, composed by informants. There were four papers which were written by different informants. For verb + noun lexical collocation, the paper 1, the informant used 2 correct and 3 incorrect collocations. The paper 2, the informant use 1 correct and 5 incorrect collocation. The paper 3, the informant does not have any incorrect collocation but only has 2 correct collocation. The paper 4 , there was 3 correct collocations and 2 incorrect collocation.

Furthermore, lexical collocation, Adj. + noun, showed that this feature has higher number of correct collocation than Verb + noun. it described for paper 1, there were at 14 correct collocation and only 2 incorrect collocation. For paper 2, there were at 3 correct collocations and 7 incorrect collocations. Next, the paper 3 , 
there was 1 correct and 11 incorrect collocation. The paper 4, there were 3 correct collocation and 4 incorrect collocation.

It can be concluded that the informants is still lack of understanding of collocation. It showed by many incorrect collocations found. Even though, in Adj. $+n$, paper 1 have fourteen correct collocation, but the awareness and ability to collocate words correctly should be improved.

1. The Lexical Collocation Errors Subtypes Were Grouped On The Basis Of The Two Types Provided In The Following Tables.

Table 1 the Number of Lexical Collocation Errors, Pattern

Subtype Identified in the Four Essays.

\begin{tabular}{|l|l|l|}
\hline Type & Pattern Identified & No. of occurrence \\
\hline \multirow{2}{*}{ Lexical error } & Verb + Noun & 10 \\
\cline { 2 - 3 } & Adj. + Noun & 29 \\
\hline
\end{tabular}

Source: MAKES Writing Production: 2016

From the table 1, the number of occurrences of the lexical errors as follows, the verb + noun occurs 10 times, and the Adj. + noun pattern occurs 29 times. In the overall, The Adj.+ noun is higher number of occurrence errors than verb+ noun. Therefore among the EFL students in this study, Adj. + noun are the most common pattern collocations. It is therefore implies that the ESL students in this study make, to a large extend, more Adj. + noun lexical collocation error than Verb + noun identified. Lexical collocation errors indentified in the discussion papers has been grouped and analyzed the causes of occurrence of errors.

a. Word Choice Errors

Table 2. Word Choice Combination Errors taken From the Discussion Paper Produced by EFL Students in the Study Group and their Equivalent Target Collocation

\begin{tabular}{|c|l|}
\hline One - Word incorrect & Equivalent Target Collocation \\
\hline a. Run test & Take a test \\
b. Take training & Have training \\
c. True threat & Real threat \\
d. Provide scholarship & Give scholarship \\
e. Superior country & Great country \\
f. Adequate education & Good/decent education \\
g. Immoral practice & Unethical practice \\
\hline
\end{tabular}

Source: MAKES Writing Production: 2016

From the table 2, it can be seen that the informants mostly used incorrect word choice combination, for instance, "immoral practice", "immoral", in this case, is improper combination of "practice" instead "unethical". It generally caused by the lack of understanding of collocation used. 


\section{b. Word Forms Errors}

The errors occur when the form of the word use is incorrect, example taken from the paper discussions include:

Table 3. Incorrect Word Form Combinations Produced by EFL Student in the Study Group and Their Target Meaning Equivalents.

\begin{tabular}{|l|l|}
\hline Word Form Incorrect & Equivalent Target Meaning \\
\hline Go bankrupt & Go into bankruptcy \\
Get panic & Get into panic \\
Moral degradation & A decline of moral \\
\hline
\end{tabular}

Source: MAKES Writing Production: 2016

In Collocation Dictionary, 2016, it defined even in the incorrect word form of combination of words categorized as a wrong collocation. It can be seen from the table 3 that word form should be considered. One of the incorrect word form is "go bankrupt", these combination of words should be added a preposition "into", without the preposition, it is incorrect collocation.

2. What are the causes and sources of collocation Errors

a. Native language Influence

Based on the analysis of data collected, there some causes and sources the collocation errors committed. Those are Native language influence, overgeneralization of rule and the lack of collocation competence. These are discussed below:

Table 4. Native Language Induced Lexical Collocation Errors Taken from the Discussion Papers Produced by Makes Members with Equivalent Target Meaning and Native Language

\begin{tabular}{|c|c|c|}
\hline $\begin{array}{l}\text { Native language induced } \\
\text { Errors }\end{array}$ & $\begin{array}{l}\text { Target } \\
\text { meaning }\end{array}$ & Native language source \\
\hline Selling sex & Sex worker & Pekerja Sex \\
\hline Unlawful trades & Illegal trades & Perdagangan illegal \\
\hline True threat & Real threat & $\begin{array}{l}\text { Ancaman yang } \\
\text { sesungguhnya }\end{array}$ \\
\hline Kill people & Massacre & Membunuh orang-orang \\
\hline Stabile condition & stability & kestabilan \\
\hline
\end{tabular}

Source: MAKES Writing Production: 2016

Based on the table 4 above, those examples are wrong collocation committed caused by the influence of the EFL student in this study. For instance, 'stable condition' which has corrects in grammatical rules but it is sound unnatural, instead of stability. Another example, 'unlawful trade', when it is converted to Bahasa, the meaning is 'perdagangan yang tak berhukum', it is happen caused, 
the Indonesian English learner or EFL/ESL students tend to compose English using translation language.

In another example, "kill people", these combinations of words are incorrect as collocation, due to the wrong contextual meaning, instead of "massacre". In Bahasa "kill" means membunuh and "people" is orang-orang (jamak) when these assembled, thus meaning is membunuh banyak orang. in English itself, these words are claimed as incorrect collocation (Collocation Dictionary: 2016), due to "kill people" is not available in Collocation Dictionary and LDOCE as well. Although these words said are grammatically corrected. "kill people" is incorrect, instead of "massacre". This phenomenon, according to Devinci in Angkana (2000: 29) occurs caused by Interlingua problem.

b. Lack of collocation knowledge.

The lack of collocation knowledge is generally manifested in the student's lack of adequate and appropriate words for self expression. Some examples are provided in Table 5.

Table 5. Collocation Errors Resulting from Lack of Knowledge Taken from the Essays Produced by ESL/EFL Students in This Study.

\begin{tabular}{|l|l|}
\hline $\begin{array}{l}\text { Wrong Combination resulting from lack of } \\
\text { knowledge }\end{array}$ & Equivalent Target Meaning \\
\hline Run test & Have a test \\
Get panic & Get into panic \\
Real threat & Real threat \\
Complementary skill & Complementary ability \\
\hline
\end{tabular}

Source: MAKES Writing Production: 2016

To sum up, there are a number of lexical collocations in MAKES writings, both L1 and L3. Nevertheless, the number of uses L3 (Adj. + noun) is higher than $\mathrm{L} 1(\mathrm{~V}+$ noun$)$ in this subject of study. Moreover, the errors occurrence among lexical collocations found were also occurred. Based on the data, mostly the informants made mistakes of lexical collocation due to Interlingua problem, direct translation and lack of understanding about collocations.

The data in this study also shows the uniqueness of choosing the topic from informants. Men are more likely to choose the topics of politics, economy, stocks, sports, and current news. While female have more interest in talking family affairs, such as the education of children, clothes, fashion, ect. It proved that the topic she choose related with a women affairs while men writing, much talking about politics news and cultures.

Moreover, it was also found that in L3, female committed many adjective patterns among male's writings. It in line with Xia, 2013:1486 that women like to use many adjective, such as adorable, charming, lovely, fantastic, heavenly, but men seldom use them 


\section{CONCLUSION}

The purpose of this study were to know English collocation, (a) verb + noun and (b) Adj.+ noun (lexical collocation) committed by MAKES member of their writing production. After analyzing the lexical collocation type L1 and L3, it was found a number of collocations, both correct and incorrect collocation.

For the type L1, it found that the number of correct collocation is higher than incorrect collocation in this subject of study. Meaning that L1 are easier than L3. There were 11 incorrect collocation found in each paper. And 8 correct collocation. There were three main causes of the errors occurrence, those are EFL students/learners are lack of collocation knowledge, Interlingua problem and native language influences. Moreover, for type L3, it was found many of lexical collocations. Although all of informants use many L3 type of collocation, but many of errors collocations committed. One of the main problem collocation errors emerged was caused by the word choice errors.

Furthermore, it also found that the topic choosing also affected by the informants' gender. Informant of Female gender was tend to use the topic related to family affairs or family and education, compare to male which tend to choose discussion topic related to politics, news and government.

\section{REFERENCE}

Angkana, m. 2008. A Study of University Student Ability in Using English Collocation, Master Project M.A (English). Bangkok: Srinnakharinwirot University.

Benson, M. E. 1986. Lexicographic Description of English. Amsterdam: Benjamins.

Buku Panduan Akademik Universitas Negeri Padang. 2008. Padang: Universitas Negeri Padang.

Gay, 1. 2009. Educational Reseach : Competencies for Analysis and Application. New Jersey: Pearson Education.

Hamdi, A. I. 2013. An Analysis of the Use of Collocation in Students' Writing. Padang: FBS University Negeri Padang.

Hammer, J. 1991. The Practice of English Language Teaching. Second Edition. Landon: Longman.

Hill, J. 2000. Revising Priorities: from Grammatical Failure to Collocational Succes, in Lewis, M. (Ed) Teaching Collocation 47-69. Croatia: Heinle.

James, C. 1998. Error in Language Learning and Use. London: Longman.

Jeanne, M. 2007. Teaching Vocubulary. Cambridge: Cambridge University Press.

Kjellmer, G. 1994. A Dictionary of English Collocations. Oxford: Clarendon Press.

Kuo, C.-L. 2009. An Analysis of the Use of Collocation by Intermediate EFL College Students in Taiwan. ARECLS, Vol.6 141-155.

Lewis, M. 2000. Teaching Collocation: Futher Development in the Lexical Approach. Oxford: Oxford University Press. 
Lewis, M. 1997. Implementing the Lexical Approach : PUTTING theory into Practice. Hove, England: Language Teaching Publication.

Lewis, M. 1993. The Lexical Approach. Hove, England: Language Teaching Publication.

Liu, C. 2000. A Study of Strategy Use in Producing Lexical Collcation. Katchen, J. And 1 Yiu-Nam, Eds. Selected Papers from Ninth International Symposium on English Teaching (PP. P.481-492). Taipei: Crane Publishing co.,ltd., 2000.

Mahmoud, A. 2005. Collocation Errors Made by Arab Learners of English. Asian EFL Journal, \%(2), Retrieved 12/01/09 , http://- www. Asian-efljournal.com/.

Mccarthy, M. A. 2008. Engliah Collocation in Advance Use. Cambridge: Cambridge University Press.

Mccarthy, Michael. 1990. Vocubulary. Oxford: Oxford University Press.

Nation, I. 2001. Learning Vocabulary in another Language. Cambridge: Cambridge University Press.

Phoocharoensil, S. 2005. Collocational Errors in EFL Learners' Interlanguage. Journal of Education and Practice, , ISSN 2222-1735 (Paper) ISSN 2222228x (online), Vol 2, No 3.

Runcia, M. 2002. Oxford Collocation Dictionary. Oxford: Oxford University press.

Sinclair, J. 1991. Corpus Concordance Collocation. Hong kong: Oxford University Press.

Sun, C. 2004. An Analysis of Lexical Collocation Errors in English Paragraph Writing of Senior High School EFL Student in Taiwan. Uk: Unpablished Master Thesis, Univerisity of Newcastle Upon Tyne.

Farrokh, Parisa. 2012. Raising Awareness of Collocation in ESL/EFL Classroom. Journal of Studies in Education, , ISSN 2162-6952 (Paper) ISSN 2162-6952 (Online), Vol 2, No 3 